\begin{abstract}
Csányi Eszter
Budapesti Gazdasági Egyetem

Pénzügyi és Számviteli Kar

Pénzügyi és Gazdálkodási Szaknyelvek Tanszék

\section{Gazdasági frazeologizmusok szemantikai elemzése}

https://doi.org/10.48040/PL.2020.8

A vizsgálat korpuszaként a WirtschaftsBlatt, a DER STANDARD, a Neue Zürcher Zeitung, a Frankfurter Allgemeine Zeitung, a DIE WELT és a WirtschaftsWoche gazdasági lapok online verziójában fellelhetö gazdasági témájú cikkeit választottam. A jelentéstani aspektus oldaláról történö osztályozáskor elsősorban az idiomatikus jelleget vizsgáltam. Amennyiben egy nyelvi egység jelentése nem adható meg az egyes elemek jelentéséböl, idiomatikus jelentésröl beszélünk. Minél nagyobb különbség van a kifejezés szó szerinti és frazeológiai jelentése között, annál nagyobb a szószerkezet idiomatizáltsági foka (vö. Fleischer, 1997; Burger, 1998; Kerékjártó, 2000; Forgács, 2007; Donalies, 2009). A korpusz elemzése során nyilvánvalóvá vált, hogy a szemantikai megközelitésben a gazdaság egyes szegmenseihez kötödnek a kigyüjtött frazeologizmusok. Így különítettem el tözsdei, makro pénzügyi, vállalati mechanizmusokhoz, folyamatokhoz, valamint általános gazdasági folyamatokhoz kapcsolódó szegmenseket.
\end{abstract}

Kulcsszavak: frazeologizmusok, gazdasági sajtó, gazdasági szaknyelv, szaknyelvoktatás, szemantika

\title{
Bevezetés
}

A gazdasági szaknyelv egy-egy nemzeti nyelv szókincsében roppant gazdag szegmens, és meglehetősen sok részterületre osztható fel, mint pl. a gazdasági élethez kötődő szövegek típusai, műfajai szerinti tagolás, melyen keresztül eljuthatunk a gazdasági sajtóhoz is.

A gazdasági szaknyelvek oktatása során rendszeresen használom a német nyelvủ gazdasági kiadványokban megjelenő szakmai témájú cikkeket, ezért jelen tanulmány alapját is a hasonló írások elemzése adta. A WirtschaftsBlatt, a DER STANDARD, a Neue Zürcher Zeitung, a Frankfurter Allgemeine Zeitung, a DIE WELT és a WirtschaftsWoche gazdasági lapok online verziójában fellelhető gazdasági témájú cikkeinek vizsgálata során a kigyüjtött gazdasági frazeologizmusokat szemantikai szempontok szerint elemeztem.

Duhme (1991) alapján szaknyelvi frazeologizmusnak tekintem azokat a frazeologizmusokat, melyek tényállásokat, illetve tárgyakat neveznek meg, szakmai karakterrel bírnak, és csak a szaknyelvben jelennek meg állandósult szókapcsolatként. Szakmai karakterük könnyen felismerhetö annak 
következtében, hogy legalább egyik tagjuk szakmaspecifikus kifejezés ( $p l$. Verluste schreiben - veszteséget könyvel el (veszteséges).

A kigyüjtött frazeologizmusok alaposabb szemrevételezése során tőzsdei, makro pénzügyi, vállalati mechanizmusokhoz/folyamatokhoz, valamint általános gazdasági folyamatokhoz kapcsolódó szegmenseket tudtam elkülöníteni. A következőkben a jelentéstani elemzés során kapott eredményeket mutatom be.

\section{A kutatás tárgya}

Az általam bemutatott vizsgálatot egy-egy szélesebb gazdasági szakmai érdeklődésű célcsoportokhoz intézett, publikus szövegen végeztem el.

A 31.266 szóból álló, 226.599 karakterszámú korpuszban (81 cikkben) összesen 621 frazeologizmust találtam. Ez átlagban 8 frazeologizmus cikkenként és egyértelmüen a frazeologizmusok gyakori használatáról tanúskodik. Ebből 214 tekinthető gazdasági frazeologizmusnak, ez 34,4\%nak felel meg, azaz cikkenként átlagban közel három gazdasági szókapcsolat fordul elö.

A gazdasági frazeologizmusok előfordulásának ez a magas aránya alátámasztja a szókapcsolatok oktatásának fontosságát a szaknyelvi órákon, hiszen az autentikus gazdasági szövegek feldolgozása során mindenképpen találkoznak a hallgatók ezekkel a nyelvi elemekkel. Elsajátításuk fontos szerepet játszik az eredeti cikkek megértésében, a szövegek közvetítésében, illetve fordításában, azaz a szaknyelvi órákon alkalmazott feladatok legtöbbjében.

A frazeologizmusok jelentéstani elhatárolásánál leggyakrabban említett kritérium az idiomatikus jelleg vizsgálata. A kutatók többsége nem idiomatikus, részben idiomatikus és teljesen idiomatikus kifejezéseket említ. Amennyiben egy nyelvi egység jelentése nem adható meg az egyes elemek jelentéséből, idiomatikus jelentésről beszélünk. Minél nagyobb különbség van a kifejezés szó szerinti és frazeológiai jelentése között, annál nagyobb a szószerkezet idiomatizáltsági foka (vö. Fleischer, 1997; Burger, 1998; Kerékjártó, 2000; Forgács, 2007; Donalies, 2009). Teljes idiomatizmusról beszélünk olyan állandósult szókapcsolatok esetén, amelyek még a részleges jelentésutalást sem tartalmazzák (vö. Földes - Kühnert, 1992; Fleischer, 1997; Forgács, 2007). Ilyenek például: in den Kinderschuhen stecken kezdetleges állapotban van; die Eule nach Athen tragen - felesleges dolgot csinálni;, unter aller Sau - nagyon rossz.

Azokat a szókapcsolatokat sorolom a gazdaságiak közé, melyek tipikusan a gazdasági tevékenységgel hozhatók összefüggésbe, illetve 
amelyeknél a főnévi-tag terminologizált. Jellemzőnek tekintem továbbá, hogy a szaknyelvben a szakmai összefüggéseket, tényállásokat egyértelmüen határozzák meg. A szaknyelvi frazeologizmusok központját szakmai terminusok képezik, és - mint fentebb szó esett erről - a gazdasági jelentésü összetétel-elem néha csak implicit van jelen. Ezen meghatározások alapján leszögezhetjük, hogy a gazdasági frazeologizmusok között igen ritka az a kifejezés, amelyik teljesen idiomatikus. A vizsgált korpuszban sem volt ilyen.

A részleges idiómák közé azok az állandósult szókapcsolatok tartoznak, amelyek egyik alkotója az eredeti jelentést tükrözi, míg a másik legtöbbször átvitt értelemben használatos. A szókapcsolatok komponensei egy új, átvitt értelmü jelentést hívnak elö (vö. Duhme, 1991; Földes Kühnert, 1992; Fleischer, 1997), pl. sich die Zähne putzen - fogat mos; blinder Passagier - potyautas; grünes Licht geben - zöld utat ad.

A gazdasági nyelv területe igen gazdag az ilyen szófordulatokban, tulajdonképpen egy, a gazdasági nyelvre jellemző frazeologizmus kialakulása figyelhető meg. A vizsgált korpuszban is számtalan példát találtam erre: der Preiswettbewerb tobt - az árverseny tombol; die Zahl sinkt auf einen Rekordtief-a szám rekord alacsony értékre esik vissza; die Exporte brachen ein - az export visszaesett. A die Exporte brechen ein - az export visszaesik kifejezésben például az export szó eredeti jelentésben van jelen, míg az einbrechen - betör valaki valahova elem csak a gazdasági környezetben, illetve szókapcsolatokban veszi fel a ,visszaesik” jelentést.

A nem idomatikus kifejezésekre az általam gyüjtött gazdasági frazeologizmusok között csupán néhány példát találtam, ezek a bei einem Wert von, illetve im Wert von - értékben, mértékben kifejezések. Igaz, a Wert - érték sem egyértelmủen gazdasági terminus, mivel más tudományterületen is előfordulhat (pl. filozófia, pszichológia, matematika). Azonban implicit módon, a szövegkörnyezet hatására beleértjük pl. Markt - piac vagy akár a Marke - márka tagokat, és így a Marktwert-piaci érték, vagy a Markenwert - a márka értéke szókapcsolatok már egyértelmúen gazdaságinak számítanak.

A nem idomatikus összetételekkel kapcsolatban fontos megemlíteni az ún. frazeológiai terminusokat is, melyek föként mondatrészértékü frazémák, s a tágabban értelmezett frazeologizmusok közé sorolhatók (vö. Fleischer, 1997; Forgács, 2007). Egy elhatárolt szakmai rendszerben értelmezett olyan tárgyat, összefüggést határoznak meg, mely normalizált és egyértelmüen definiálható. A „legalább két szóból álló szaknyelvi kifejezések" (Forgács, 2007:92) úgy viselkednek, mint bármelyik egy szóból álló szakkifejezés, azaz jelentésük kötött és csak egy bizonyos szakmai alrendszeren belül értelmezhető (vö. Burger - Buhofer - Sialm, 1982; Duhme, 1991; Burger, 1998; Forgács, 2007). A frazeológiai terminusok, mint 
nem idiomatikus kifejezések szintén nagy számban fordultak elő a vizsgált anyagban, s leginkább a fönév + melléknév összetételek voltak jelen: eine leichte Belebung - enyhe javulás; fauler Kredit - kockázatos hitel; stille Reserve - rejtett tartalék.

\section{A gazdasági frazeologizmusok csoportosítása}

A korpusz elemzése során kikristályosodott, hogy szemantikai megközelítésben a gazdaság egyes szegmenseihez kötődnek a kigyüjtött frazeologizmusok. Így hoztam létre a tőzsde, a makro pénzügyek, az általános gazdasági folyamatok (pl. piac, kereskedelem), és a vállalati mechanizmusok/folyamatok csoportjait.

$\mathrm{Az}$ egyes szegmensekbe történő besorolás nem mindig egyszerü. Vannak olyan kifejezések, amelyeket több szegmenshez is lehetne sorolni pl. Geld in Aktien anlegen - pénzt fektet be részvényekbe: tartozhat a tözsde vagy a pénzügyek fogalomköréhez is, vagy az einen Rückgang der Nachfrage verzeichnen (Zeitung) - visszaesést ér el/visszaesik a kereslet (újság) kifejezés besorolható a vállalatok/cégek vagy akár a gazdasági folyamatok témakörébe is.

$\mathrm{Az}$ 1. diagram az egyes szegmensekhez tartozó kifejezések számát mutatja az összes gazdasági frazeologizmust tekintve. Láthatjuk, hogy a legtöbb kifejezés (79) a vállalati mechanizmusok, folyamatok csoporthoz, míg a legkevesebb (25) a tőzsde témához kapcsolódott. A makro pénzügyek (39) és az általános gazdasági folyamatok (42) számadatai nagyjából megegyeznek. A vállalatok a gazdaság mozgatórugói, a gazdaság legfontosabb szereplői közé tartoznak. Éppen ezért gyakran alanyai a gazdasági témájú újságcikkeknek is.

1. diagram. Az egyes gazdasági szegmensekhez tartozó gazdasági frazeologizmusok

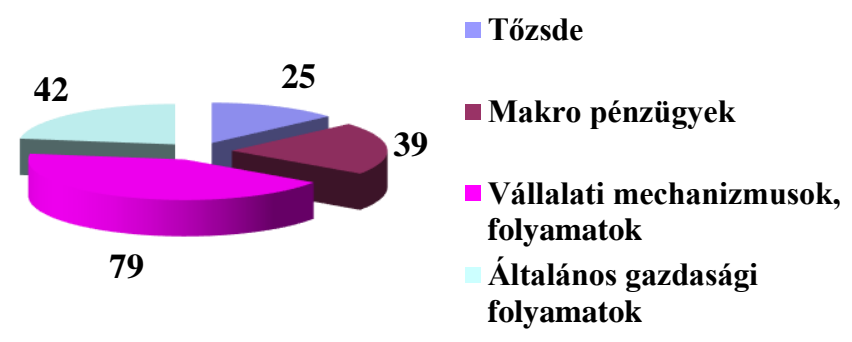

A következőkben az egyes szegmensekhez tartozó frazeologizmusokkal foglalkozom behatóbban. A gazdasági szegmensek elnevezéseit magyarul, a hozzájuk tartozó bázisszavakat - az újságcikkek nyelvére tekintettel - elöször magyarul, majd az előfordulás eredetijében, 
németül tüntetem fel. A kifejezések mögött álló forrásjelölések a következők: WB: WirtschaftsBlatt, DS: DER STANDARD, NZZ: Neue Zürcher Zeitung, FAZ: Frankfurter Allgemeine Zeitung, DW: DIE WELT, WIWO: WirtschaftsWoche. Az 1-22 számok az egyes lapok adott cikkeit jelölik.

A tőzsdei kifejezések közé soroltam az árfolyam, a (tőzsdei hangulatot jelző) barométer, az emelkedés, az érték, az értékpapir, a növekedés és a veszteség (árfolyamot tekintve), a részvény, a tözsde és a trend szavakat tartalmazó kifejezéseket. A 25 szókapcsolatban megtalálható kifejezés számszerüsített eloszlását ld. a 2. diagramon.

2. diagram. Egyes tőzsdei kifejezések előfordulása

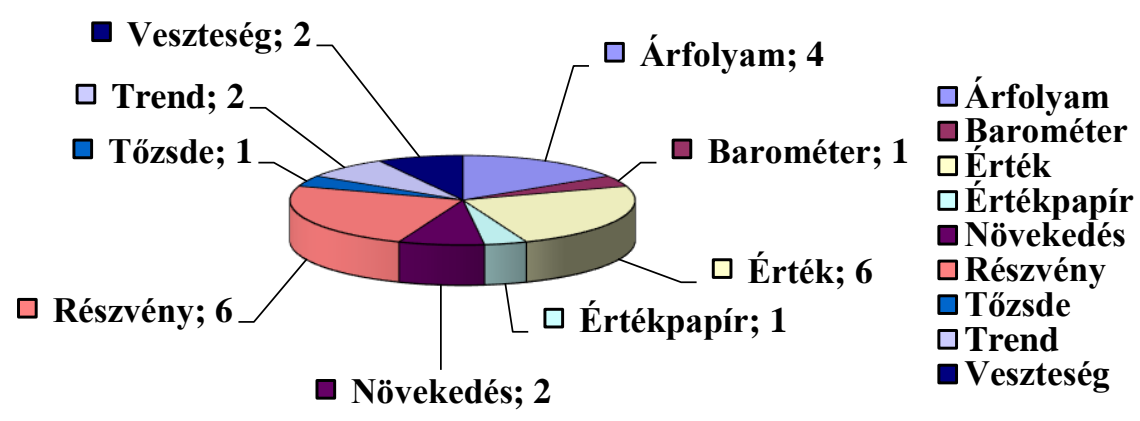

Látható, hogy az érték (Wert) és a részvény szavakkal találtam a legtöbb szókapcsolatot (6-6). Pl. die (10.000-Punkte-)Marke knacken átlépi/túlszárnyalja a határt/értéket (FAZ 9); auf ein Jahrestief fallen - az éves legalacsonyabb értékre esik (FAZ 9); ein Rekordhoch markieren (DAX) - rekord magas eredményt ér el (DW 5); Aktien ausgeben - részvényt kibocsájt (DS13); in Aktien anlegen - részvényekbe fektet be (FAZ 8, FAZ 8); die Aktie handeln - részvénnyel kereskedik (WIWO 1).

Az árfolyam báziskomponenshez négy különbözö kifejezést találtam, a növekedés, a trend és a veszteség 2-2 összetételben fordult elő. Érdekes viszont, hogy konkrétan a tözsde szakszóhoz csupán egy kifejezést találtam: an die Börse gehen - tözsdére megy/részvényeket ad el a tözsdén (FAZ 10), éppúgy, mint a barométer szóhoz: Börsenbarometer - a tözsdei befektetési kedvet jelzö adat (DW 5). Az érték, az árfolyam, a részvény, a növekedés, a trend, a veszteség és a tözsde szavak tipikusan a gazdasághoz kötődnek, míg a barométer-t általában az időjárással kapcsolatban alkalmazzák (igaz ott is az előrejelzést szolgáló müszer neve).

A makropénzügyi szegmenshez soroltam többek között a bank, az adózás, az árak alakulása, az érték (mint mennyiség), a fizetéssel, a hitelekkel, a kamatokkal, a pénzzel, a tökével és a vagyonnal kapcsolatos 
frazeologizmusokat. A 39 kifejezésben összesen 20 báziskomponenst találtam, melyek számszerüsített eloszlását az 3. diagram mutatja be.

A makropénzügyek szegmenshez tartozó összetételek közül egyértelmủen kiemelkednek a pénzzel kapcsolatosak, ami nem meglepő a témakört tekintve pl. Geld abknöpfen - pénzt gombol le róla (DW 9); Geld anlegen - pénzt fektet be (FAZ 8); Geld verdienen - pénzt keres (WB 4, NZZ 9, FAZ 3). A második helyen négy kifejezéssel az ár (Preis) báziskomponens áll pl. den Preis entrichten - kifizeti az árat (DW 6); die Preise kippen ins Negative - veszteségessé válik, mínuszba fordulnak az árak (NZZ 9). Ezt követik az adat, az érték, a hitel, a fizet fogalomkörök 3-3 kifejezéssel pl. Bankdaten hinterlegen - banki adatokat letétbe helyez (FAZ 10), Bankdaten preisgeben - kiadni a banki adatokat (FAZ 10), (Onlinebank)Daten eingeben - online banki adatokat megad (FAZ 10). Látható, hogy az adat báziskomponens esetén mindhárom kifejezés a bankkal kapcsolatos, ami a pénzügyi szektor egyik legfontosabb eleme. Ezután a vagyon báziskomponens következik 2 kifejezéssel: (Geld)vermögen anhäufen vagyont halmoz fel (FAZ 5), Vermögen besitzen - vagyonnal rendelkezik (WB 7). Végül az adó, az adósság, a bizonyit, az eszköz, a garancia, a határ, a kamatemelés, a kockázat, a költség, az összeg, a számla, a teher, a töke, a vas, a veszteség és a visszaesés báziselemekkel 1-1 kifejezést találtam a makro pénzügyek szegmensen belül.

A kifejezések legtöbbje megfelel a makropénzügyi szegmenssel kapcsolatos tevékenységeknek, és a szegmens elemeinek úgymint az adózás, a bankok, a biztositók és a fizetés.

3. diagram. A makropénzügyek szegmensbe tartozó báziselemek

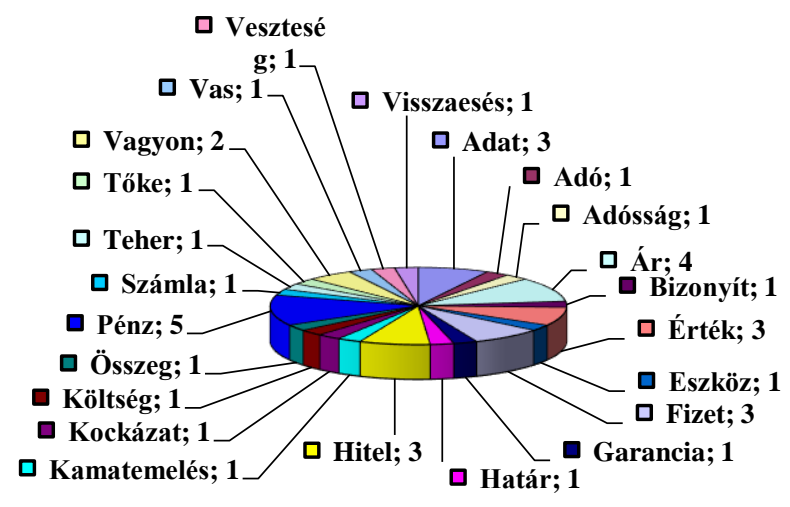

\begin{tabular}{|c|c|c|c|c|}
\hline $\begin{array}{l}\text { 口Adat } \\
\text { 口Érték } \\
\text { 口Hitel } \\
\text { 口Pénz }\end{array}$ & $\begin{array}{l}\text { 口Adó } \\
\text { 口Eszköz } \\
\text { 口Kamatemelés } \\
\text { 口Számla }\end{array}$ & $\begin{array}{l}\text { 口Adósság } \\
\text { 口Fizet } \\
\text { 口Kockázat } \\
\text { 口Teher }\end{array}$ & $\begin{array}{l}\text { 口Ár } \\
\text { 口Garancia } \\
\text { 口Költség } \\
\text { 口Tőke }\end{array}$ & $\begin{array}{l}\text { 口Bizonyít } \\
\text { 口Határ } \\
\text { 口Összeg } \\
\text { 口Vagyon }\end{array}$ \\
\hline
\end{tabular}


A vállalati mechanizmusok, folyamatok szegmenséhez tartozónak tekintettem egyebek mellett az (üzleti) adatokkal, az alkalmazottakkal/munkahelyekkel, a csöddel, az értékcsökkenéssel, a nyereséggel, a sztrájkkal és a veszteséggel összefüggésben álló kifejezéseket. Mindezek összefüggésbe hozhatók egy vállalat mindennapi müködésével, tevékenységeinek lebonyolításával. Ide tartozott a legtöbb frazeologizmus, szám szerint 79 . Ez véleményem szerint tükrözi azt, hogy a gazdasági élet legfontosabb szereplöi a cégek, így a gazdasági témájú cikkek legtöbbje is róluk szól. Összesen 44 báziskomponenst állapítottam meg. A munkahely és a nyereség fogalomhoz tartozott a legtöbb kifejezés (6-6) pl. Arbeitsplätze abbauen - munkahelyeket szüntet meg (DS 8); Stelle(n) entstehen munkahely(ek) jön(nek) létre (FAZ 12); Gewinn abwerfen - nyereséget könyvel el/ér el (NZZ 9); einen Gewinn erwirtschaften - nyereséget ér el (NZZ 4).

A megbizás és a veszteség báziskomponensek szintén igen magas előfordulással voltak jelen (5-5), ami nem meglepö, hisz egy vállalat müködésében ezek a legfontosabb dolgok. Az osztalék (3), a cégalapitó (3), a cég (2), az eredmény (2), érték (2), az értékesités (2), a költség (2), a nyomás (2), az üzlet (2) és a verseny (2) báziskomponenseken kívül az összes többi összetevő csupán 1-1 szókapcsolattal szerepelt. A csoport báziskomponenseit közelebbről megnézve látható, hogy azok a vállalatok szokásos tevékenységeivel vannak összefüggésben. A két leggyakoribb báziselem, a munkahely és a nyereség (6-6 szókapcsolat), valamint a szintén nagy számmal előforduló megbízás és veszteség (5-5) összetevők, éppúgy, mint, az adat, a vállalat, az osztalék, a verseny, a tartalék, a kockázat, a költség, a megbizás, a termelés, a hozam stb. fogalmak is fontosak a cégek mindennapjaiban.

Az általános gazdasági folyamatokhoz kapcsolódó szókapcsolatok köre elég sokszínü. A 42 kigyüjtött frazeologizmus között megtalálhatók voltak az egyes gazdasági mutatókkal kapcsolatos kifejezések, úgymint GDP, konjunktúra, munkanélküliség, piac, versenyhelyzet, növekedés, recesszió és válság. A fogalomcsoporthoz tartozó összetételek tükrözik a piaci eseményekhez, gazdasági ágazatokhoz köthető legfontosabb gazdasági szókapcsolatokat is. Pl. (die Branche) steckt in den Kinderschuhen - (az ágazat) gyerekcipöben jár (NZZ 9); der Preiswettbewerb tobt - az árverseny tombol (FAZ 6); die Exporte brachen ein - visszaesett az export (DS 4); der (wirtschaftliche) Nutzen fällt gering aus - alacsony a (gazdasági) haszna (NZZ 1).

A négy szegmens közül ebben van a második legtöbb frazeologizmus, ami a kifejezések tág keretét tükrözi. Több olyan szókapcsolat is van, ami ugyanazzal a báziskomponenssel áll összefüggésben, illetve szinonim jelentéssel bír. Például einen (BIP) Anstieg anpeilen-emelkedést/növekedést 
céloz meg (WB 14); ein (leichtes) Plus verzeichnen (bei Arbeitslosenzahl) (kis/enyhe) nyereséget jegyez/könyvel el (WB 11); Wachstum erzielen növekedést ér el (DS 4, FAZ 5); einen leichten Zuwachs verzeichnen - kisebb növekedést ér el (DS 4). Az érték, az ingatlanpiac és a piac szavak 2-2 szókapcsolattal, míg az összes többi komponens csupán 1-1 összetétellel volt jelen.

A három leggyakoribb szókapcsolat az érték (13), a növekedés (10) és a veszteség (8) báziskomponenssel állók voltak, ami bizonyítja, hogy a gazdasági tevékenységgel (legyen az egy vállalkozás, az állam vagy akár a tőzsde) kapcsolatban ezek a fogalmak igen fontos szerepet játszanak. A legmagasabb számú érték báziselem mindegyik szegmensben megtalálható volt (13 szókapcsolatban), igaz a tőzsde szegmensében majdnem annyi összetétel volt (6), mint a másik három szegmensben összesen (makro pénzügyek: 3 , általános gazdasági folyamatok: 2 , vállalati mechanizmusok, folyamatok: 2). A növekedés összetevő 8-szor fordult elő az általános gazdasági folyamatok szegmensében és 2-szer a tőzsde szegmensében. A veszteség elem pedig legtöbbször a vállalati mechanizmusok, folyamatok szegmensében (5-ször), 2-szer a tözsde szegmensében és 1-szer a makro pénzügyi szókapcsolatok között volt jelen. Emellett 1-1 összetevővel számos szókapcsolatot találtam ( $\mathrm{pl}$. adó, ajánlat, ágazat, csöd, eredmény, eszköz, export, haszon, hozam, kereslet, müködés, töke, vezetö stb.).

\section{Konklúzió}

A szaknyelvi frazeologizmusokon belül a cikk a gazdasági frazeologizmusokkal foglalkozik. Ez alatt azokat a kifejezéseket értem, melyek jelentése tipikusan gazdasági tevékenységekkel hozható összefüggésbe, illetve a fönévi tag terminologizált. A definiálásnál lényeges szempont, hogy számos frazeologizmus a szakmai (gazdasági) szövegkörnyezet következtében válik gazdaságivá.

A szövegekben fellelhető 621 frazeologizmusból 214 tekinthető gazdasági frazeologizmusnak, amelyek között 185 különbözö báziskomponenst azonosítottam. Ez 34,4\%-nak felel meg, ami cikkenként átlagban $3(2,9)$ gazdasági szókapcsolatot jelent. Ez a magas arány is alátámasztja a frazeologizmusok oktatásának fontosságát a gazdasági szaknyelvi órákon, mivel az autentikus gazdasági szövegek feldolgozása során mindenképpen találkoznak a hallgatók ezekkel a nyelvi elemekkel.

A gazdasági frazeologizmusok szemantikai szempontok alapján történő osztályozáskor elsősorban az idiomatikus jelleg volt a vizsgálat tárgya, ami a leggyakrabban említett kritérium a frazeologizmusok elhatárolásánál. A vizsgált szövegekben nem fordult elő teljesen idiomatikus 
kifejezés, és a nem idiomatikus kifejezésekre is csupán néhány példát hozott a vizsgált anyag. Ugyanakkor részleges idiómákban, illetve frazeológiai terminusokban, mint idiomatikus kifejezésekben az elemzett cikkek igen gazdagok voltak.

A szemantikai megközelítésnél különböző gazdasági szegmensekhez kapcsolódó összetevők, a tőzsde, a makro pénzügyek, a vállalati mechanizmusok, folyamatok, illetve az általános gazdasági folyamatok körébe tartozó szókapcsolatok kristályosodtak ki.

A szemantikai elemzés megmutatta, hogy a gazdasági életben fontos események, a gazdasági alanyokhoz kapcsolódó kifejezések voltak jelen a vizsgált korpuszban. A legtöbb frazeologizmus (76) a vállalati mechanizmusok, folyamatok csoporthoz, míg a legkevesebb (25) a tőzsde témához kapcsolódott. A makro pénzügyek (39) és az általános gazdasági folyamatok (42) szegmensek számadatai nagyjából megegyeznek.

A gazdasági felsőoktatásban a kötelező szakmai idegennyelv-tanulás keretein belül a hallgatók megismerkednek a gazdasági szaknyelv legfontosabb témaköreivel, kifejezéseivel. A tankönyvek törekednek arra, hogy mind tartalmilag, mind nyelvileg tükrözzék a gazdaság és az azt leképező szaknyelv aktuális állapotát és folyamatait, azonban ezek kiegészítéseként az oktatók nagy része szívesen nyúl autentikus újságcikkekhez, melyek akár elektronikus, akár nyomtatott formában ma már mindenki számára könnyen elérhetők.

A gazdasági szaknyelvi órákon a receptív készségeken belül nagy hangsúlyt kell fektetni az olvasott szöveg értés készségének fejlesztésére autentikus gazdasági újságcikkek segítségével is, mivel a receptív készségek közvetetten a produktív készségeket is fejlesztik. Tapasztalataim szerint a hallgatók nem rendelkeznek megfelelő ismeretekkel a gazdasági szaknyelvi frazeologizmusok terén (vö. Csányi, 2017). Éppen ezért szükség van a gazdasági szaknyelvi órákon az idegen nyelvi gazdasági frazeologizmusok oktatására. A gazdasági frazeologizmusok értése, illetve használata sokszor már magyar nyelven is problémát okoz, így azok elmagyarázása, megtanítása is gyakran az idegen nyelvet tanító tanárokra hárul.

\section{Hivatkozások}

Burger, H. (1998): Phraseologie. Eine Einführung am Beispiel des Deutschen. Erich

Schmidt Verlag: Berlin. DOI: https://doi.org/10.1515/9783110849394

Burger, H. - Buhofer, A. - Sialm, A. (Ed.) (1982): Handbuch der Phraseologie. Walter de Gruyter: Berlin, New York

Csányi, E (2017): Frazeologizmusok a német gazdasági sajtóban, helyük a gazdasági szaknyelv elsajátításában. Doktori PhD értekezés. PTE Nyelvtudományi Doktori Iskola: Pécs. Online elérhető: 
https://pea.lib.pte.hu/bitstream/handle/pea/16381/csanyi-eszter-phd-

2017.pdf? sequence $=1$ \&is Allowed $=y$

Donalies, E. (2009): Basiswissen. Deutsche Phraseologie. A. Franke/UTB: Tübingen und Basel

Duhme, M. (1991): Phraseologie der deutschen Wirtschaftssprache: eine empirische Untersuchung zur Verwendung von Phraseologismen in journalistischen Fachtexten. Die Blaue Eule: Essen

Fleischer, W. (1997): Phraseologie der deutschen Gegenwartssprache. 2. Auflage. Niemeyer Verlag: Tübingen. DOI: https://doi.org/10.1515/9783110947625

Forgács, T. (2007: Bevezetés a frazeológiába. A szólás- és közmondáskutatás alapjai. Segédkönyvek a nyelvészet tanulmányozásához 69. Tinta Könyvkiadó: Budapest

Földes, Cs. - Kühnert, H. (1992): Hand- und Übungsbuch zur deutschen Phraseologie. Egységes jegyzet. Tankönyvkiadó: Budapest

Kerékjártó, Á. (2000): Frazeológia a magyar nyelv tanitásában. Hungarológia/(2000) 1-2. 223-247. Online elérhetö:

http://epa.oszk.hu/02400/02472/00013/pdf/EPA02472_Hungarologia_2000_2_12_223-247.pdf 